Original Research Paper

\title{
Development of "Immersion and Plated Filtering" as an Alternative of VCO Making
}

\author{
Dalmadi* \\ Pranata Laboratorium Pendidikan (PLP) Laboratorium Pendidikan Biologi FKIP, Universitas Mataram, \\ Mataram, Indonesia
}

\author{
Article History \\ Received : February $02^{\text {th }}, 2019$ \\ Revised : May $22^{\text {th }}, 2019$ \\ Accepted : June $04^{\text {th }}, 2019$ \\ Published : June $12^{\text {th }}, 2019$ \\ *Corresponding Author: \\ Dalmadi, \\ Pranata Laboratorium Pendidikan \\ (PLP) Laboratorium Pendidikan \\ Biologi FKIP, Universitas \\ Mataram, \\ Mataram, Indonesia \\ Email:dalmadylbk@gmail.com
}

\begin{abstract}
The purpose of this study was to determine the quality of VCO oil made using the Layered Induction and Filtering technique. This research is an experimental study using the Layered Induction and Filtering method in making VCO oil. The population used as the object of this research is coconut in the Mataram city area, which is the raw material for making VCO oil. While the sample used is old and dry coconut fruit. The data from the calculation of the VCO quality test were obtained using the standard formula for calculating the quality of oil to test for moisture, peroxide numbers and free fatty acids. The results of the water content test at an interval of one hour for four times were $0.15 \%$, the test results for the peroxide number were 2.46 and the acid number test results were $0.46 \%$. Based on APCC (Asian and Pacific Coconut Community) standards, VCO oil made with the Layered Induction and Filtering technique has the quality of the water content, peroxide number, and free fatty acids below the maximum standards set by APCC, so the quality of VCO oil is very good. Making VCO with this method can be applied on a household scale with the quality of results according to the standards set by the APCC.
\end{abstract}

Keywords: VCO, Settling and Filtering, Moisture Content, Peroxide Number, Free Fatty Acids

\section{Pendahuluan}

Indonesia merupakan negara tropis yang memilki potensi tinggi terhadap kelapa. Selama ini kelapa sebagaian besar diolah menjadi kopra untuk bahan dasar pembuatan minyak kelapa salah satunya adalah minyak kelapa murni (Virgin Coconut Oil/VCO). VCO merupakan salah satu produk yang dihasilkan dari kelapa yang saat ini sedang ramai diperbincangkan karena berbagai manfaat yang dihasilakan terutama untuk tubuh manusia. Berbeda halnya dengan minyak kelapa yang dibuat secara konvensional, VCO diolah dengan bahan baku kelapa segar tanpa melalui proses penyulingan, sehingga suhu yang digunakan dalam proses ini lebih rendah (Elfianus, 2008).

Hasil kromatografi gas spektrofotometri massa, asam lemak yang terkandung dalam VCO yaitu asam kaproat $(0.187 \%)$, asam oktanoat $(1,12 \%)$, asam siklopropanapentanoat $(0.54 \%)$, asam laurat $(32,73 \%)$, asam miristat $(28,55 \%)$, asam palminat $(17,16 \%)$, asam oleat $(14,09 \%)$, dan asam stearat $(5,68 \%)$ (Novilla, 2017). Berbagai macam kandungan asam lemak jenuh dan tidak jenuh dalam VCO terbukti dapat membantu meningkatkan daya tahan tubuh terhadap berbagai macam penyakit serta mempercepat proses penyembuhan.
Minyak VCO murni banyak digunakan dalam industri farmasi, kosmetika, susu formula, maupun sebagai minyak goreng mutu tinggi. Minyak VCO murni dapat menanggulangi beragam penyakit pada manusia (Hasibuan, 2018). Untuk pengobatan penyakit, Minyak VCO murni digunakan untuk mengobati HIV-AIDS, kanker, hepatitis, osteoporosis, diabetes, penyakit jantung, obesitas, dan berbagai macam penyakit yang disebakan oleh mikroba. Berbagai macam manfaat yang bisa di dapatkan dari VCO ini juga dapat dijadikan salah satu alternatif peningkat imunitas tubuh di tengah situasi pandemi Covid-19 yang sedang menjangkit hampir seluruh negara di dunia. Virgin coconut oil (VCO) atau kadang juga disebut minyak kelapa murni mempunyai kandungan asam lemak rantai sedang atau medium chain fatty acids (MCFA) yang mudah diurai oleh tubuh dengan jumlah yang sangat tinggi. Disamping itu VCO juga mempunyai kandungan antioksidan seperti tokoferol dan betakaroten yang sangat tinggi. Karena banyaknya kandungan MCFA dan antioksidan dalam VCO, maka minyak ini dapat digunakan untuk menjaga kesehatan tubuh serta menangkal berbagai penyakit berbahaya seperti penyakit jantung, kolesterol dan stroke (Sutanto, 2017).

Virgin coconut oil (VCO) merupakan 
minyak yang diperoleh tanpa mengubah sifat fisiko kimia minyak karena hanya diberi perlakuan mekanis dan penggunaan panas rendah. VCO banyak mengandung asam laurat dan asam lemak jenuh berantai pendek, sehingga VCO memiliki peran positif Virgin coconut oil (VCO) merupakan minyak yang diperoleh tanpa mengubah sifat fisiko kimia minyak karena hanya diberi perlakuan mekanis dan penggunaan panas rendah. VCO banyak mengandung asam laurat dan asam lemak jenuh berantai pendek, sehingga VCO memiliki peran positif (Aditiya, 2014).

Dalam proses pembuatannya, VCO dapat mengguanakan berbagai macam metode, diantaranya; metode enzimatis, metode fermentasi, metode pemancingan, metode sentrifugasi, metode pemanasan terkendali, dan metode pengasaman. Berbagai macam metode tersebut memiliki kelebihan dan kekurangannya masing-masing.

Pembuatan VCO metode enzimatis menggunakan enzim untuk membantu memecah protein yang berperan sebagai pengemulsi dalam santan (Winarti, 2007). Kelebihan penggunaan metode ini menghasilkan VCO dengan warna yang jernih dengan kandungan asam lemak dan antioksidan yang tidak berubah dan bau yang tidak mudah tengik. Namun dalam pembuatannya metode ini membutuhkan waktu yang sangat lama dalam proses denaturasi protein untuk memisahkan minyak dari ikatan lipoprotein, yaitu sekitar 20 jam.

Metode pengasaman dilakukan dengan membuat suasana emulsi (santan) dalam keadaan asam. Berdasarkan penetiltian terdahulu, pembuatan minyak kelapa dengan cara ini lebih cepat menghasilkan minyak, karena kondisi asam dapat menyebabkan protein kehilangan sifatnya sebagai emulsifier sehingga terjadi pemisahan minyak dengan air (Salsabila, 2016). Pembuatan dengan metode ini cukup sulit dilakukan karena keadaan $\mathrm{pH}$ campuran (santan dan asam) harus pas yaitu 4,3, apabila pH campuran kurang atau lebih kemungkinan kegagalan sangat tinggi.

Metode produksi lain yaitu teknik pancingan yang membutuhkan waktu lebih dari 10 jam untuk 1 (satu) batch produksi dan teknik fermentasi beresiko adanya kontaminasi bakteri sehingga yield tidak optimal, sedangkan proses pemurniannya membutuhkan teknik sentrifugasi dengan investasi alat lebih besar dan kurang cocok untuk industry rumahan (Susanto, 2012).

Dalam praktikum mahasiswa FKIP Universitas Mataram pembuatan VCO dilakukan dengan menggunakan metode fermentasi. Metode ini menggunakan bantuan mikroba berupa ragi/permifan sebagai fermentor. Penggunaan permifan dalam pembuatanVCO seringkali menghasilkan minyak VCO dengan kualitas yang bening namun agak kekuningan dan masih berbau tengik (kurang sedap).

Melihat berbagai fenomena di atas, dalam penelitian ini peneliti ingin mengkaji tentang metode pembuatan VCO terbaru dengan menggunakan teknik Pendiaman dan Penyaringan Berlapis terhadap kualitas minyak VCO.

\section{Bahan dan Metode}

Penelitian ini adalah penelitian eksperimental dengan menggunakan metode Pendiaman dan Penyaringan Berlapis dalam pembuatan minyak VCO. Populasi yang dijadikan sebagai objek penelitian ini adalah kelapa di daerah kota mataram yang merupakan bahan baku pembutan minyak VCO. Sedangkan sampel yang digunakan adalah buah kelapa tua dan kering. Penentuan sampel didasarkan dengan menggunakan teknik purposive sampling, berdasarkan pengambilan sampel dengan menmpertimbangkan tujuan dari penelitian (Sugiyono, 2003).

Adapun yang menjadi variabel bebas dari penelitian ini adalah pembuatan VCO dengan metode pendiaman dan penyaringan berlapis terhadap kualitas VCO yang dihasilkan sedangkan variabel terikatnya adalah kualitas minyak VCO berdasarkan analisis standar keawetan minyak. Data hasil perhitungan uji kualitas VCO di dapatkan dengan menggunakan rumus standar perhitungan kualitas minyak untuk uji kadar air bilangan peroksida, dan asam lemak bebas.

\section{Hasil dan Pembahasan}

Metode Pendiaman dan Penyaringan Berlapis merupakan metode terbarukan dalam pembuatan VCO. Merode ini berbeda dengan berbagai metode pembuatan VCO sebelumnya seperti pemanasan terkendali, fermentasi, pemancingan, penambahan enzim ataupun sentrifugasi. Metode ini dapat dilakukan dengan mudah dan menggunakan alat-alat yang sederhana.

Pada metode ini kelapa tua dan kering yang telah di parut ditambahkan air bersih sampai kelapa mudah diperas. Air yang digunakan adalah air yang memiliki suhu ruang $\left(32^{\circ} \mathrm{C}\right)$, penggunaan air yang bersuhu tinggi dapat meningkatkan kandungan asam lemak bebas yang dapat merusak kualitas VCO dan mempengaruhi warna minyak yang dihasilkan. Hasil campuran parutan kelapa dan air didiamkan sampai 2 jam sehingga terbentuk lapisan kanil (santan kental) dan air. Lapisan santan kanil dipisahkan dengan air untuk selanjutnya di diamkan kembali selama minimal 8 jam dan maksimal 24 jam. Berbeda halnya dengan metode-metode pembuatan VCO yang telah ada dimana santan kanil pada umumnya diberi berbagai macam perlakuan seperti sentrifugasi menggunakan mixer atau alat sentrifugal, penambahan asam, enzim, atau fermentor dalam santan kanil, atau bahkan dengan pemancingan menggunakan VCO yang telah tersedia, pada penelitian ini santan kanil tidak diberi perlakuan apapun atau hanya di biarkan selama beberapa waktu sehingga mengalami fermentasi sendiri atau biasa disebut sebagai fermentasi spontan. 
Fermentasi spontan adalah fermentasi yang dilakukan tanpa adanya penambahan mikroorganisme dalam suatu bahan pangan. Fermentasi spontan adalah fermentasi yang biasa dilakukan menggunakan media penyeleksi, seperti garam, asam organik, asam mineral, nasi atau pati (Sari, 2018). Media penyeleksi tersebut akan menyeleksi bakteri patogen dan menjadi media yang baik bagi tumbuh kembang bakteri selektif yang membantu jalannya fermentasi.
Dalam proses fermentasi santan kanil ini, pengaturan suhu dan keberadaan oksigen sangat berpengaruh terhadap VCO yang dihasilkan. Santan kanil difermentasi dalam keadaan anaerob dengan suhu ruang berkisar $25^{\circ} \mathrm{C}-27^{\circ} \mathrm{C}$. Apabila suhu ruang berada dibawah atau diatas suhu ruang tersebut, maka suhu dikondisikan dengan penambahan bola lampu pada lemari penyimpanan.

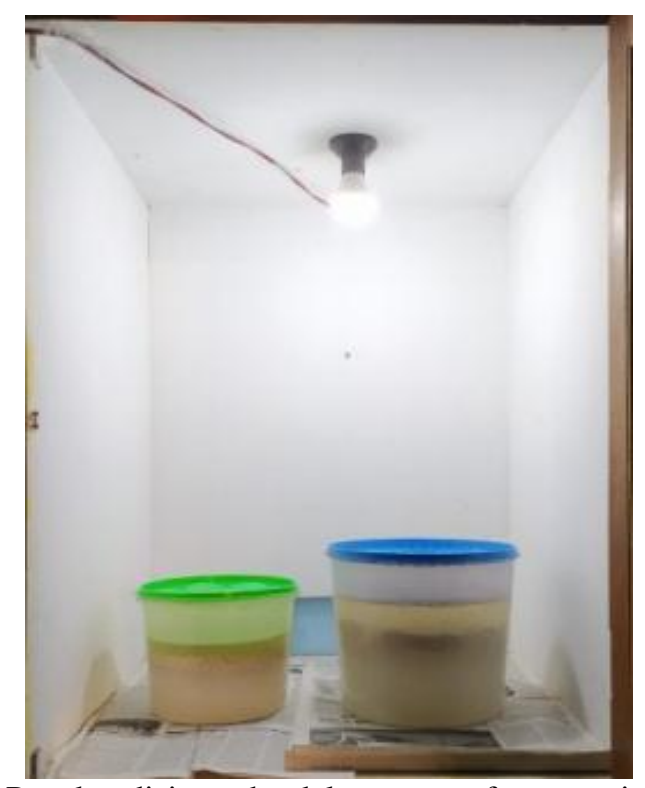

Gambar 1. Pengkondisian suhu dalam proses fermentasi santan kanil

Prinsip fermentasi spontan yang terjadi pada santan kanil adalah rusaknya emulsi antara minyak dan protein yang disebabkan oleh mikroba alami dalam kelapa. Rusaknya protein maka ikatan lipoprotein dalam santan akan terputus dengan sendirinya (Asiah, 2019). Kemudian minyak yang diikat oleh ikatan tersebut akan keluar, dan protein akan menggumpal menjadi satu. Karena minyak memilki massa jenis yang lebih rendah dibandingkan air, maka posisinya akan berada dipaling atas disusul dengan protein dan air.

Santan kanil yang telah didiamkan selama lebih dari 8 jam akan menghasilkan 3 lapisan yaitu lapisan blondo (protein), minyak dan air. Lapisan minyak ini kemudian dipisahkan dengan penyaringan berlapis menggunakan kertas saring dan kapas kosmetik. Penyaringan ini dilakukan sempai 7 kali sampai dihasilkan minyak yang jernih.

Penyaringan pertama dilakukan dengan menggunakan kapas kosmetik, minyak yang telah dipisahkan dengan air dan blondonya disaring menggunakan kapas kosmetik 1 lapis. Hasil saringan pertama ini kemudian disaring kembali menggunakan selapis kertas saring (penyaringan ke-2), penyaringan ke-3 dilakukan dengan menggunakan 2 lapis kertas saring. Penyaringan dilakukan sampai 7 kali dengan penyaringan terakhir menggunakan 6 lapis kertas saring. Penyaringan berlapis ini dimaksudkan untuk mendapatkan kualitas minyak VCO yang bagus baik dari segi warna maupun untuk meminimalisir kandungan air yang mungkin masih ada dalam minyak. Metode ini mampu menghasilkan VCO dengan jumlah 2,5 liter sampai 2,8 liter untuk 30 biji kelapa.

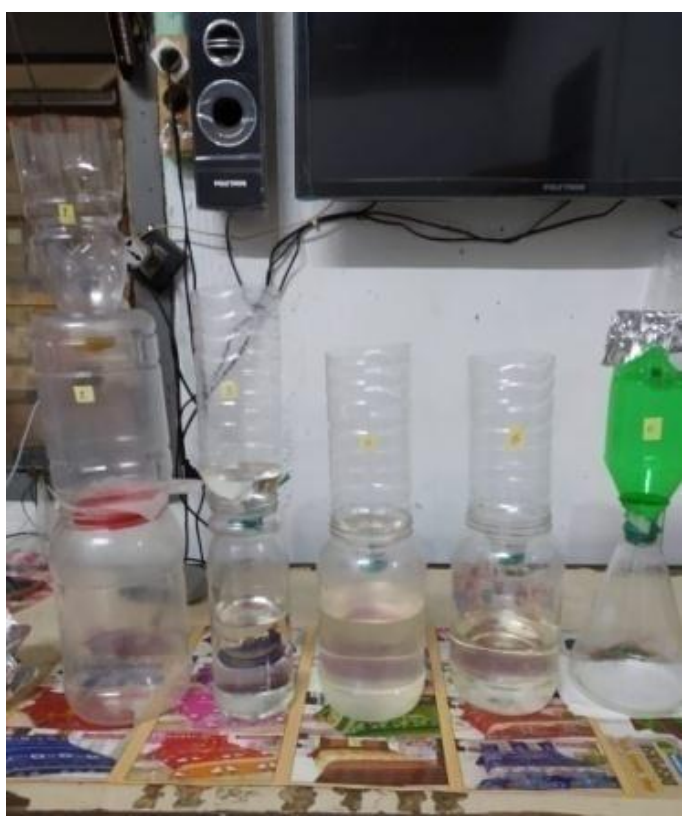

Gambar 2. Proses penyaringan minyak VCO 
Minyak VCO hasil pembuatan dengan metode Pendiaman dan Penyaringan Berlapis berdasaran pengamatan fisik dengan pancaindera manusia, memiliki warna putih jernih, dengan bau khas minyak kelapa yang tidak tengik. Untuk mengetahui kualitas minyak VCO dilakuakan berbagai macam uji yang standarnya mengacu kepada standar mutu yang ditetapkan APCC (Asian and Pacific Coconut Community) berupa analisis kualitas fisik, analisis standar kewetan minyak, analisis komposisi asam lemak dan analisis keberadaan logam pada minyak. Menurut standar APCC (Asian and Pacific Coconut Community) khasiat minyak VCO tergantung pada komposisi asam-asam lemaknya. Penentuan komposisi asam-asam lemak dilakukan dengan kombinasi metode Gas Chromato-graphy dan Mass Spectroscopy (GC-MS)
(Asy'ari, 2006).

Uji kromatografi minyak VCO yang dihsilkan melalui metode Pendiaman dan Penyaringan Berlapis dapat dilihat pada gambar 3. Pada tabel 1 terebut, terdapat bebarapa asam lemak bebas yang terkandung di dalam minyak antara lain; asam laurat, asam stearat, asam miristat, asam palmitat, asam decanoat dan asam oleat. Kandungan asam lemak jenuh terutama asam laurat sangat bermanfaat untuk kesehatan dan imunitas tubuh.

Selain di uji kromatgrafinya, minyak VCO yang diperoleh dalam penelitian ini dilakuakan analisis standar keawetan dengan beberapa parameter yang berkaitan dengan rusaknya minyak VCO. Parameter yang diamati antara lain adanya peroksida, asam lemak bebas dan kandungan air.

\section{Chromatogram vco-dalmadi C:IGCMSsolution lata ruru 5 ivco-dalmadi.QGD}

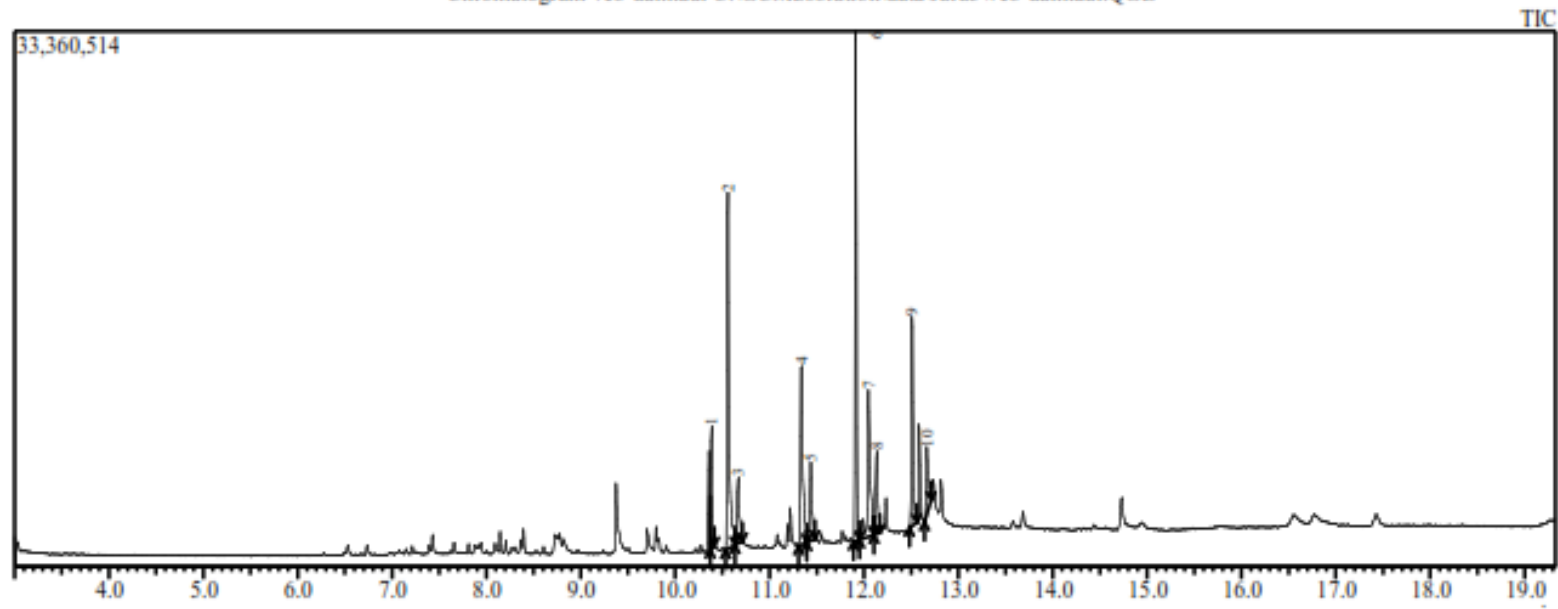

Gambar 3. Spektrum hasil uji GCMS minyak VCO

Tabel 1 Asam lemak bebas yang minyak VCO

\begin{tabular}{lll}
\hline No & Rumus & Senyawa \\
& kimia & \\
\hline 1 & $\mathrm{C}_{14} \mathrm{H}_{22} \mathrm{O}$ & 2,4-di-tert-butilfenol \\
2 & $\mathrm{C}_{14} \mathrm{H}_{24} \mathrm{O}_{2}$ & Lauric acid \\
3 & $\mathrm{C}_{18} \mathrm{H}_{36} \mathrm{O}_{2}$ & Stearic acid \\
4 & $\mathrm{C}_{14} \mathrm{H}_{28} \mathrm{O}_{2}$ & Myristic acid \\
5 & $\mathrm{C}_{16} \mathrm{H}_{32}$ & Hexadecene \\
6 & $\mathrm{C}_{17} \mathrm{H}_{34} \mathrm{O}_{2}$ & Hexadecanoic acid/ Methyl palmite \\
7 & $\mathrm{C}_{16} \mathrm{H}_{32} \mathrm{O}_{2}$ & Palmitinic acid \\
8 & $\mathrm{C}_{18} \mathrm{H}_{36}$ & Octadecene \\
9 & $\mathrm{C}_{19} \mathrm{H}_{36} \mathrm{O}_{2}$ & 9-octadecanoic acid \\
10 & $\mathrm{C}_{18} \mathrm{H}_{34} \mathrm{O}_{2}$ & Oleic acid \\
\hline
\end{tabular}

\section{Kadar air}

Jumlah kadar air dalam minyak sangat berpengaruh terhadap cepat atau tidaknya minyak menjadi tengik. Hal ini disebabkan adanya air akan menyababkan terjadinya reaksi hidrolisis sehingga terbentuk asam lemak bebas pada minyak. Jumlah kadar air dalam minyak juga berpengaruh terhadap warna minyak pada proses pemucatan dan jumlah kadar asam lemak bebas yang terkandung dalam minyak (Sari, 2018). Semakin tinggi jumlah kadar air, maka akan semakin terang warna minyak (tidak bening) dan semakin tinggi pula jumlah asam lemak bebas yang dikandungnya. 
Kandungan air yang terdapat pada minyak juga dapat meningkatkan pertumbuhan mikroorganisme dalam minyak. Pertumbuhan mikroorganisme tersebut tentu saja dapat mempengaruhi kualitas fisik minyak baik itu berupa bau dan warnanya.

Penetuan kadar air dalam penelitian ini mengguankan metode gravimetri. Prinsip dalam metode ini adalah mengetahui jumlah air dalam sampel dengan cara menimbang berat awal sampel sebelum di panaskan dan setelah di panaskan. Pemanasan sampel dilakuakan didalam oven dengan suhu $105{ }^{\circ} \mathrm{C}$ selama 3 jam dengan menimbang berat sampel setiap $1 \mathrm{jam}$.

Berdasarkan tabel 2 di atas jumlah kadar air yang terbentuk pada VCO adalah $0.15 \%$, jumlah ini di bawah standar maksimal yang ditetapkan oleh APCC sebesar $0.1 \%-0.5 \%$.

Air dalam bahan makanan terdapat dalam berbagai bentuk diantaranya adalah air terikat secara lemah, air terabsorbsi (terserap) pada permukaan makromolekuler seperti protein, pectin, pati, sellulosa, dsb Muharun, 2014). Keberadaan air dalam minyak dapat merusak kualitas akibat reaksi hidrolisa (Aisyah, 2010).

\section{Bilangan peroksida}

Salah satu parameter rendahnya kualitas minyak adalah jumlah kadar peroksida dalam minyak tersebut. Adanya peroksida dalam minyak akan menyebabkan terjadinya reaksi oksidasi dan radikal bebas sehingga dapat menurunkan mutunya. Cara yang sering digunakan untuk menentukan angka peroksida adalah dengan metoda titrasi iodometri.

Dari hasil uji bilangan peroksida tabel 3 jumlah kadar peroksida dalam sampel minyak VCO rata-rata sebesar $2.46 \mathrm{meg} / \mathrm{kg}$. Jumlah kadar peroksida tersebut masih berada di bawah standar maksimum jumlah peroksida yang di tetapkan APCC (Asian and Pacific Coconut Community) sebesar $3 \mathrm{meg} / \mathrm{kg}$.

Kerusakan minyak yang utama adalah karena peristiwa oksidasi, hasil yang diakibatkan salah satunya adalah terbentuknya peroksida dan aldehida. Peroksida dapat mempercepat proses timbulnya bau tengik dan flovour yang tidak dikehendaki dalam bahan pangan (Aisyah, 2010).

Tinggi rendahnya jumlah bilangan peroksida tergantung dari jumlah lemak yang telah mengalami oksidasi dengan oksigen. Kecepatan oksidasi ini bias disebabkan oleh beberapa hal seperti paparan oksigen, cahaya dan suhu. Pada proses pembuatan minyak VCO tidak digunakan pemanasan, sehingga jumlah bilangan peroksida yang dihasilkan lebih sedikit daripada minyak curah pada umumnya.

\section{Kandungan Asam lemak Bebas (FFA)}

Asam lemak bebas adalah asam lemak yang berada sebagai asam bebas tidak terikat sebagai trigliserida. Asam lemak bebas dihasilkan oleh proses hidrolisis dan oksidasi biasanya bergabung dengan lemak netral. Hasil hidrolisis ini akan menghasilkan gliserol dan asam lemak bebas (Fadhli, 2015).

Penetapan kadar asam lemak bebas pada penelitian ini menggunakan metode alkalimetri dimana prinsip metode yang digunakan yaitu terjadinya reaksi netralisasi akibat adanya reaksi antara ion hidrogen yang berasal dari asam yang berasal dari minyak dengan ion hidroksida yang berasal dari basa yang digunakan pada pentiter. Pentiter pada penelitian ini menggunakan $\mathrm{KOH} 0.1 \mathrm{~N}$ dimana $\mathrm{KOH}$ tersebut digunakan sebagai penetral asam lemak bebas yang terdapat dalam sampel minyak.

Berdasarkan table 3 tersebut hasil perhitungan jumlah asam lemak bebas sampel minyak VCO rata-rata sebesar $0.46 \%$. Jumlah asam lemak bebas sampel VCO tersebut masih berada di bawah standar maksimum yang di tetapkan APCC (Asian and Pacific Coconut Community) sebesar $0.5 \%$.

Jumlah kadar asam lemak pada minyak VCO dapat dipengaruhi oleh adanya reaksi lemak yang terdapat dalam minyak dengan oksigen yang ada $\mathrm{d}$ udara. Terbentuknya asam lemak bebas oleh reaksi kimia hidrolisa dipercepat oleh keberadaan air dalam bahan (Muharun, 2014).

Pembentukan $F F A$ menjadi salah satu parameter kerusakan minyak karena semakin tinggi kadar $F F A$ minyak maka semakin rendah mutu minyak (Balung, 2013). Proses berlangsung sejak minyak pertama kali diperam yaitu ketika pemisahan krim dan skim. Selanjutnya krim dibiarkan selama 12 jam, guna menurunkan $\mathrm{pH}$ krim agar supaya protein sebagai zat penstabil emulsi dapat rusak hingga pada akhirnya akan terbentuk lapisan minyak, protein dan air. Proses terbentuknya asam ini mempercepat terjadinya hidrolisis gliserida menjadi gliserol dan asam lemak bebas.

Tabel 2. Hasil jumlah kadar air VCO

\begin{tabular}{cccc}
\hline Jam ke- & Berat wadah & Berat sampel + wadah & \% kadar air \\
\hline 0 & 26.29 & 32.80 & \\
1 & 26.29 & 32.79 & 0.15 \\
2 & 26.29 & 32.79 & 0.15 \\
3 & 26.29 & 32.79 & 0.15 \\
\hline
\end{tabular}


Table 3. Bilangan peroksida sampel minyak VCO

\begin{tabular}{cccc}
\hline Ulangan I & Ulangan II & Ulangan III & Rata-rata $(\Sigma)$ \\
\hline 2.2 & 2.6 & 2.6 & 2.46 \\
\hline
\end{tabular}

Tabel 3. Hasil perhitungan asam lemak bebas sampel VCO

\begin{tabular}{cccc}
\hline Ulangan I & Ulangan II & Ulangan III & Rata-rata $(\Sigma)$ \\
\hline $0.45 \%$ & $0.49 \%$ & $0.45 \%$ & $0.46 \%$ \\
\hline
\end{tabular}

\section{Kesimpulan}

Berdasarkan standar APCC (Asian and Pacific Coconut Community), minyak VCO yang dibuat dengan teknik Pendiaman dan Penyaringan Berlapis memiliki kualitas jumlah kadar air, bilangan peroksida, serta asam lemak bebas dibawah standar maksimal yng ditetapkan APCC, sehingga mutu dari minyak VCO sangat baik. Pembuatan VCO dengan metode ini dapat diaplikasikan dalam skala rumah tangga dengan kualitas hasil sesuai standar yang ditetapkan APCC. Perlu dilakuakan penelitian lebih lanjut mengenai standar analisis fisik dengan uji organoleptik pada minyak VCO metode Pendiaman dan penyaringan berlapis.

\section{Ucapan Terima Kasih}

Terima kasih penulis ucapkan kepada semua fihak yang telah membantu dan mendukung baik moril maupun materil. Penelitian ini menggunakan dana pribadi. Terima kasih juga kepada teman - teman laboran PMIPA FKIP Universitas Mataram.

\section{Referensi}

Aditiya, R., Rusmarilin, H., \& Limbong, L. N. (2014). Optimasi pembuatan virgin coconut oil (vco) dengan penambahan ragi roti (Saccharomyces cerevisiae) dan lama fermentasi dengan vco pancingan. Jurnal Rekayasa Pangan Dan Pertanian, 2(2), 51-57.

Aisyah, S., Yulianti, E., \& Fasya, A. G. (2010). Penurunan angka peroksida dan asam lemak bebas (FFA) pada proses bleaching minyak goreng bekas oleh karbon aktif polong buah kelor (Moringa oliefera. Lamk) dengan aktivasi $\mathrm{NaCl}$. Alchemy, 1(2), 53103.

Asiah, N., Astuti, R. M., Cempaka, L., \& Setiani, R. (2019, December). Physical and Chemical Characteristic of Virgin Coconut Oil under Mix Culture Fermentation Technique. In Journal of Physics: Conference Series, 1364 (1), p. 012009. IOP Publishing.
Asy'ari, M., \& Cahyono, B. (2006). Pra-standarisasi: produksi dan analisis minyak virgin coconut oil (VCO). Jurnal Kimia Sains dan Aplikasi, 9(3), 7480 .

Bolung, Y. Y., Mamuaja, C. F., Mandey, L. C., \& Mamahit, L. P. (2013, May). Kajian Mutu Fisik dan Kimia Virgin Coconut Cooking Oil (VCCO) dari Beberapa Varietas Kelapa (Cocos nucifera L.). In $\operatorname{Cocos}, 2$ (4).

Elfianus, G. (2008). Teknik pengolahan Virgin Coconut Oil menggunakan ragi tape. Buletin Teknologi Pertanian, 13, 69-72.

Fadhli, H., Teruna, H. Y., Jose, C., \& Hendra, R. (2015). Isolasi B-amirin Dari Kulit Batang Pulai Basung (Alstonia spatulata B1.). Jurnal Penelitian Farmasi Indonesia, 4(1), 1-5.

Hasibuan, C. F., Rahmiati, R., \& Nasution, J. (2018). Pembuatan Virgin Coconut Oil (VCO) Dengan Menggunakan Cara Tradisional. Martabe: Jurnal Pengabdian Kepada Masyarakat, 1(3), 128-132.

Muharun, M., \& Apriyanto, M. (2014). Pengolahan Minyak Kelapa Murni (Vco) Dengan Metode Fermentasi Menggunakan Ragi Tape Merk Nkl. Jurnal Teknologi Pertanian, 3(2), 9-14.

Novilla, A., Nursidika, P., \& Mahargyani, W. (2017). Komposisi asam lemak minyak kelapa murni (Virgin Coconut Oil) yang berpotensi sebagai anti kandidiasis. EduChemia (Jurnal Kimia dan Pendidikan), 2(2), 161-173.

Salsabila, M. (2016). Pembuatan Minyak Kelapa Dengan Pengasaman (Jeruk Nipis) Dan Penetralan Dengan Nahco3 Beserta Uji Kualitasnya (Doctoral dissertation, Universitas Negeri Semarang).

Sari, O. P. A. (2018). Studi Fermentasi Spontan Metode Tetap Dan Tidak Tetap Terhadap Karakteristik Tepung Modifikasi Biji Nangka (Artocarpus heterophyllus. L) (Doctoral dissertation, STIKES 
Dalmadi (2019). Jurnal Biologi Tropis, 19 (1): 116 - 122

DOI: http://dx.doi.org/10.29303/jbt.v19i1.1007

PKU Muhammadiyah Surakarta).

Coconut Oil (VCO) Dengan Metode Tanpa

Pemanasan Sebagai Upaya Meningkatkan

Sugiyono (2003). Metode Penelitian Administrasi.

Kesehatan Masyarakat. Dharma Raflesia: Jurnal Bandung: Alfabeta.

Ilmiah Pengembangan dan Penerapan IPTEKS, 15(1).

Susanto, T. (2012). Kajian metode pengasaman dalam proses produksi minyak kelapa ditinjau dari mutu produk dan komposisi asam amino blondo. Jurnal Dinamika Penelitian Industri, 23(2), 124-130.

Sutanto, T. D., \& Ratnawati, D. (2017). Pembuatan Virgin

Winarti, S., \& Jariyah, P. Y. (2007). Proses pembuatan VCO (virgin coconut oil) secara enzimatis menggunakan papain kasar. J Teknol Pertan, 8(2), $136-41$. 